Seton Hall University

eRepository@Seton Hall

Library Publications

University Libraries

2013

\title{
Are print books dead? An investigation of book circulation at a mid-sized academic library
}

Lisa Rose-Wiles

Seton Hall University

Follow this and additional works at: https://scholarship.shu.edu/lib_pub

Part of the Library and Information Science Commons

\section{Recommended Citation}

Rose-Wiles, Lisa, "Are print books dead? An investigation of book circulation at a mid-sized academic library" (2013). Library

Publications. 58.

https://scholarship.shu.edu/lib_pub/58 


\section{ARE PRINT BOOKS DEAD? AN INVESTIGATION OF BOOK CIRCULATION AT A MID-SIZED ACADEMIC LIBRARY.}

\section{PREPRINT}

The published version of this article is available in Technical Services Quarterly 30.2 (2013): 129-152.

Dr. Lisa M Rose-Wiles

Science Librarian / Assistant Professor

Seton Hall University

400 South Orange Avenue

South Orange, NJ 07079-2671

Email: lisa.rose-wiles@shu.edu 
Abstract: I analyzed circulation of print books at Seton Hall University Libraries using the WorldCat Analysis tool and Voyager data. Only 21.5\% of our collection circulated between 2005 and 2009, but circulation varied by subject area. Circulation was higher for subjects with more current collections. Over one-third of recent science books circulated, while older science books had low circulation. Print book circulation declined by 23\% between 2005 and 2009 . Results of this study informed collection development and prompted a comprehensive weeding project, participation in an international scholarly reading study, and an e-book, patron-driven acquisition program.

Keywords: circulation, science books, WorldCat analysis tool, patron-driven acquisition.

Running Head: are print books dead?

In most academic libraries today, shrinking budgets coupled with rising costs have seriously eroded purchasing power, leading to cuts in many areas of library expenditure and bringing all under close scrutiny. Electronic databases and journals consume a large and growing part of most library materials budgets. Print books may represent a relatively small proportion of the budget, but book purchases may be cut strategically to reduce overall expense, or simply because there is little money left once commitments to database and journal subscriptions have been met. In addition, as reliance on electronic resources increases, print book use is declining, and many librarians fear that books will sit unread upon shelves, gathering dust and taking up valuable space. Electronic books (e-books) offer a tempting alternative, particularly under the recent "patron-driven acquisition" (PDA) model, where book records are placed in the library's online catalog but need not be purchased until some predetermined threshold of use. 
In this paper, I examine the circulation of our print book collection, particularly in the sciences, with the aim of informing future decisions about collection development, book budget allocations, and possible investment in a PDA e-book collection.

Seton Hall University (SHU) is a private, Catholic diocesan university located in South Orange, New Jersey. It is the oldest diocesan university in the United States and is classified as a doctoral research university with balanced arts and sciences/professions. As of fall 2010, SHU had an enrollment of 8,603, including 5,301 undergraduates (90\% full-time) and 3,402 graduate students, 38\% full-time (Seton Hall University Fact book 2010-11). SHU’s Walsh library houses the Walsh Gallery, Monsignor William Noé Field University Archives, and numerous special collections as well as extensive collections of print books and journals. However, online databases and journals account for over $65 \%$ of our materials budget. A National Endowment for the Humanities grant has funded the purchase of humanities resources since 1990, but we rely on our general budget for almost all other information resources. Non-humanities book purchases declined from almost $16 \%$ of the materials budget in fiscal year 2008 to $3.3 \%$ in 2010 . While the decline in book purchases seems alarming, it may be appropriate if there is a corresponding reduction in demand for and use of print books. To help address this question, I undertook an analysis of our print book and e-book holdings and circulation patterns.

\section{Literature Review}

As academic libraries increasingly invest in electronic resources, investment in print books and print book circulation have typically declined (Carlson, 2001; Martell, 2008; Anderson, 2011; Bullis \& Smith, 2011; Kolowich, 2011; Rose-Wiles, 2011; Stewart, 2011a). The Association of Research Libraries (ARL) 2008-9 report indicates that the median ARL 
university library spent $56 \%$ of its materials budget on electronic materials (Kyrillidou \& Morris, 2011). Between 1991 and 2009, the median number of monographs purchased increased by $24 \%$, and the median expenditure on monographs increased by $41 \%$. During the same period, median reported expenditure on serials rose from $\$ 2,548,677$ to $\$ 7,193,291$, an increase of $182 \%$. The proportion of the materials budget spent on serials rose from $63 \%$ to $71 \%$, while the proportion spent on monographs fell from $35 \%$ to $19 \%$,

The subscription-based service ACRLMetrics provides access to Association of College \& Research Libraries (ACRL) statistics and the National Center for Education Statistics (NCES) Academic Libraries Survey data (Stewart, 2011b). ACRLMetrics for 324 reporting doctoral granting institutions indicate that in fiscal year 2010, the median proportion of the materials budget spent on electronic resources was $66 \%$ and the median spent on monographs was $14 \%$. This is a substantial reduction from the median of 39\% that 423 doctoral institutions spent on monographs in 2000.

The ARL report for 2008-9 showed a 27\% drop in median values reported for initial circulation (checkouts excluding renewals) and a 19\% decrease in total circulation since 1991 (Kyrillidou \& Morris, 2011). ACRLMetrics annual circulation reports indicate a 7\% decline in initial circulations and a 12\% decline in total circulations between 2000 and 2009. The number of libraries reporting circulation figures decreased from 424 to 315 (27\%) during the same period.

Anderson (2011) notes that raw circulation figures underestimate the drop in monograph use, since library holdings and student enrollment typically increase over time. Anderson found that for many ARL libraries, measuring book circulation per student over time showed a 
considerably greater decline in the use of print books than indicated by the raw data alone. Martell (2008) used a ratio of "median circulations to median full-time students” to illustrate declining circulation among ARL libraries.

Variation among libraries in terms of collection and circulation of print books is to be expected. In his report on ACRLMetrics, Stewart (2011b) includes a sample trend report for his own library at the Illinois Institute of Technology showing that book circulation increased by 29\% between 2007 and 2009. Yet in the same year, he reported the results of the Cornell “Report of the Collection Development Executive Task Force on Print Collection Usage,” noting that 55\% of print monographs purchased since 1990 have never circulated, and that this is a typical value for ARL institutions. Trueswell (1969) is credited with the " $80 / 20$ rule" that $20 \%$ of the library collection accounts for $80 \%$ of its circulation, but exceptions to the rule have been reported. Eldredge’s 1998 study of monograph circulation at University of New Mexico Health Sciences Center Library found that 36\% of monographs accounted for $80 \%$ of circulation, and 84\% of monographs acquired 5 years earlier had circulated at least once. Blecic (2000) reported a similar pattern at the Library of Health Sciences Chicago: $38 \%$ of monographs accounted for $80 \%$ of circulation, and $81.5 \%$ of monographs studied circulated at least once in a 3-year period. Dinkins (2003) found that at Stetson University, circulation patterns varied by subject area and were also affected by whether books were selected by librarians or department faculty. Music books selected by librarians had the highest proportional circulation: 39\% of books accounted for $80 \%$ of circulation.

Another approach to collection evaluation examines circulation of subject collections in relation to their representation in a library’s total holdings. Bonn (1974) developed a “use factor” based on a subject's relative proportion of circulation transactions divided by the 
subject’s proportion of library holdings. Mills (1981) multiplied Bonn’s “use factor” by 100 to give a "percentage of expected use" or PEU. The assumption was that expected use should be $100 \%$, i.e. that proportional circulation should match proportional holdings. PEUs greater than $100 \%$ indicated a collection was over-used for its size, and PEUs less than $100 \%$ indicated under-use. Aguilar (1986) suggested that PEUs more than one standard deviation from the mean should be considered overused or underused, and also used interlibrary loan requests to generate a "ratio of borrowings to holdings" (RBH) as a measure of collection health. Ochola (2002) used PEU and RBH to identify underused and overused subject collections at Baylor University.

Knievel et al. (2006) used "percentage of collection circulated by subject" and "average number of transactions per item per subject” to inform collection development and assessment at the University of Colorado at Boulder and also included interlibrary loan statistics. Cheung et al. (2011) examined circulation of books at Lingnan University in Hong Kong over a 15-year period. They found that almost $65 \%$ had been checked out at least once, but books that did not circulate within the first few years of purchase were unlikely to circulate at all.

Knievel et al. (2006) urge librarians to use detailed circulation data and statistics to inform "evidence-based decision making” in this era of decreasing library budgets. Ten years earlier, Carrigan (1996) had reported that despite increasing demand for libraries to provide more resources with lower budgets and growing pressures of fiscal accountability, most libraries did not use circulation data to inform collection management. The most commonly cited reasons were system limitations and insufficient years of data being available. Despite advances in computer technology, collecting and analyzing holdings and circulation data remains time consuming and challenging. Hughes (2012) developed a computer program to produce reports 
with detailed subject-level use and in-house use of print books at New York University, but many libraries do not have access to this level of expertise.

One useful aid, the WorldCat Collection Analysis tool (WCA), is offered by OCLC on a subscription basis (OCLC, n.d.; Orcutt \& Powell, 2006). Mallery \& Theus (2012) used the WCA in a pilot project to assess subject collections and inform cooperative collection development. It was through their work that we became aware of the WCA and undertook a trial subscription in 2009. A number of studies report using the WCA to evaluate their own library collections and/or compare local holdings with peer or aspirant libraries (e.g. Beals \& Gilmour, 2007; Neubert \& Brewer, 2007; Henry et al. 2008; Culbertson \& Wilde, 2009; McClure, 2009; Monroe-Gulick \& Currie, 2011). Davis et al. (2008) used the WCA interlibrary loan module to inform strategic collection development at North Carolina State University, and Way's (2009) use of the WCA interlibrary loan data prompted a decision to develop a patron-initiated purchase program at Grand Valley State University. However, few studies appear to have used the WCA circulation module as a collection analysis tool.

An additional factor to consider in regard to collection and circulation of print books is the increasing availability and popularity of e-books (Blummer \& Kenton, 2012). Academic libraries have been somewhat slow to adopt e-book collections, especially compared with their rapid adoption of online journals (Connaway \& Wicht, 2007; Jackson, 2008), but the pace of ebook collection and use seems to be accelerating. Miller (2011) reported a 93\% increase in academic library e-book collections since 2010. A survey of academic library directors sponsored by Ithaka S+R found that many library directors expect to spend nearly half their book budget on electronic books within the next 5 years (Long \& Schonfeld, 2010). However, this would still only represent about $10 \%$ of the library materials budget and does not appear to 
presage the demise of print books. Only 7\% of responding directors agreed with the statement that "the use of electronic versions of scholarly monographs will be so prevalent among faculty and students that it will not be necessary to maintain library collections of hard-copy books.” (Long \& Schonfeld, 2010, p. \#30). In a similar study of faculty, 31\% expected that e-books will be valuable in five years as compared to only $13 \%$ today, but "virtually all respondents dismiss the notion that e-books will displace print originals in a relatively short timeframe” (Schonfeld \& Housewright, 2010, p. \#23).

The future of e-books in academic libraries will likely depend on the extent to which students and faculty discover and use them. The ebrary 2007 survey, which was completed by 906 faculty members from 300 institutions, found that $79 \%$ of faculty preferred print to e-books for extensive research (Jackson, 2008). The ebrary 2011 global student e-book survey found that $54 \%$ of students said they used e-books, a modest increase compared to the 52\% who reported using e-books in 2008 (McKiel, 2011). However, 47\% still reported "never using e-books," the most common reasons being "I do not know where to find them" and "I prefer printed books." By comparison, the JISC National e-book Observatory project in the UK found that nearly 65\% of students and instructors had used e-books, and that 52\% of the e-books (including e-text books) were obtained through the library (JISC, 2009).

There is growing evidence that e-books are used differently from print books. They are often preferred when searching for quick information or reading short sections, but most users prefer print books for lengthy readings or extensive research (Shelburne, 2009; Berg et al., 2010; Blummer \& Kenton, 2012). The JISC study also found that e-books were used for "quick fact extraction and brief viewing." Only $5 \%$ of users spent more than 5 minutes on a page, and only 5.5\% of students and 7.1\% of teachers read an entire e-book. Shrimplin et al. (2011) report four 
distinct opinions regarding e-books among students at Miami University, which they refer to as “book lover,” “technophiles,” “pragmatists,” and “printers.” Woody et al. (2010) found that while students recognize that e-books have advantages such as full-text search options, portability, flexibility, and off-campus access, most still prefer print textbooks to e-textbooks.

Numerous studies have compared the use of print and e-books (e.g. Dillon, 2001; Littman, 2002; Littman \& Connaway, 2004; Christianson, 2005; Christianson \& Aucoin, 2005; Williams \& Best, 2006; Ugaz \& Resnick, 2008; Slater, 2009; Kimball et al., 2010). Most found that e-books had similar or somewhat higher use than print books, but patterns vary among libraries, user groups, and subject area. Subject areas that typically have high e-book usage include computer science, business, and medicine. However, as often reported for print books, a small number of titles frequently account for a high proportion of use.

It is difficult to determine what constitutes "use" of e-books and how to compare this with print book usage. The use of print books is typically measured in terms of checkouts, but ebook usage reports provided by vendors are not standardized and may include a range of metrics such as sessions, page views, downloads, and/or pages printed (Cox, 2008; Kraus, 2009; Sprague \& Hunter, 2009; Blummer \& Kenton, 2012). Williams \& Best (2006) note the disparity between print and e-book usage statistics: circulation statistics for print books do not account for "inhouse use" and that e-book accesses may be the equivalent of "taking a book off the shelf, glancing at it and then replacing it” (p.\#476).

A relatively recent development in e-books is the "patron-driven acquisition” (PDA) model, in which e-books are made available - typically through a library’s online catalog - but need not be purchased until some predetermined threshold of use is reached (Nixon et al., 2010). 
The PDA model is based on demand rather than speculation (Knievel et al., 2006), or "just in time” instead of "just in case" collection development. Many librarians had misgivings about abdicating responsibility for collection development, fearing runaway expenses or inappropriate patron choices. Some negative experiences have been reported (e.g., Hodges et al. 2010), but others have been positive, finding that patron choices are typically similar to librarian choices (Price \& McDonald, 2009; Shen et al., 2011). Under some models, librarians choose PDA ts individually rather than downloading a collection selected by a vendor or publisher, allowing tighter control of the titles that are available for patrons to select (Dinkins, 2012). Patron-driven e-book acquisition was among the 2012 "top ten trends" in academic libraries (ACRL Research Planning \& Review Committee, 2012) and appears to be here to stay.

\section{Results}

\section{Print book holdings}

I used OCLC's WorldCat Collection Analysis (WCA) tool to generate a picture of our print book collection by subject area and publication date range as of July, 2011. I used the collection analysis module, with format limited to "books." The initial results are displayed within 32 subject divisions, described as "broad disciplines of knowledge (and) not tied to a specific classification scheme” (OCLC, n.d.). I grouped these divisions into 14 broader subjects

plus government documents. For some analyses, I further collapsed these into five general subject areas: humanities, social sciences, health and medical sciences, science, and business. I combined date ranges into eight periods (pre-1900, 1900-1950, and subsequently by decade) for 
ease of presentation. I excluded 585 books with no recorded publication date from analyses involving publication date ranges. WCA results were exported as text files and imported into Microsoft Excel 2010, where I completed all subsequent analyses.

The WCA shows that over 59\% of our 443,577 print books are in humanities subjects. About 13\% fall under social science; business and science account for 6.6\% and 6.4\% respectively, and health and medical sciences books account for 5\% (see Table 1). The three subjects with the largest collections are literature and language, philosophy and religion, and history (see Table 2). Examining the collection by publication date range shows increases in non-humanities books published since the 1960s, but humanities titles dominate in every period, including the 2000s (books published between 2000 and 2011; see Table 1). Over 70\% of our current book holdings published since 2000 are in the humanities, compared with $12 \%$ in the social sciences, $5 \%$ in the health and medical sciences, and $4 \%$ each in business and science. The humanities collection is also the most current, with $21 \%$ of currently held humanities titles being published since 2000 compared with about $11 \%$ of science and business titles (see Table 1).

Table 1 about here

Table 2 about here

\section{Print Book Circulation}

I used the WCA circulation analysis function "circulation ratio", limited to format "books," to examine the circulation of our print book collection. The only data provided by WCA circulation analysis are for 2005-9. The analysis can be limited by subject and by year, but circulation data for earlier or more recent years are not available. For each OCLC “division” the 
analysis provides total titles held, total titles circulated, percent of titles circulated, titles not circulated, total checkouts, and average checkouts per title circulated for the 5-year period.

I followed the approach of Knievel et al. (2006), determining the percentage of our collection circulated by subject and the average number of transactions per book by subject. Overall, 21.5\% of our print books (excluding government documents and "other") circulated at least once between 2005 and 2009, with an average of 1.88 checkouts per title circulated. However, there is considerable variation between subjects (see Table 2). Art books have the highest circulation, with $28.6 \%$ circulating at least once between 2005 and 2009. Literature has the lowest circulation at $9.2 \%$, followed by science with $12.2 \%$ of books circulating. The average number of checkouts per title circulated also varied by subject area, with science the lowest at 1.66 and health \& medical sciences the highest at 2.13 checkouts. There is a significant positive correlation between the percentage of a subject collection published between 2000 and 2011 and the percentage of the subject collection that circulated $(r=0.614$, d.f. $12, p<0.05)$, suggesting that recent books are more likely to circulate than older books.

The WCA's "total checkouts" is a measure of all circulation transactions, combining the number of books circulating with the number of times each book is checked out for the period 2005-9. Following the approach of Mills (1988) and Ochola (2002), I calculated the "percentage of expected use” (PEU) for each of 15 subject areas, excluding government documents and including 585 books with no publication date given (see Table 3). By this measure, the most heavily used subject collection is sociology, followed by health and medical science, while the least heavily used are science and "other." The latter finding is unsurprising as the category “other” includes reference books. The PEU was greater than 100\% for eight subject areas and less than $100 \%$ for six subject areas. Sociology fell more than one standard deviation above the 
mean, Aguilar’s (1986) standard for “over-use”, while science and “other” fell more than one standard deviation below the mean, indicating "under-use”. There was no significant correlation between PEU and currency, as measured by the percentage of books in a subject area published between 2000 and 2011 ( $r=0.236$, d.f. 12, p > 0.05).

\section{Table 3 about here}

The WCA can provide total checkouts by year for the period 2005-2009 under the tab “circulation date.” These data indicate a 23\% decline in annual checkout rates, from $8.1 \%$ in 2005 to $6.2 \%$ in 2009 (see Table 4). The decline is most notable in the humanities and social sciences. The annual rate of science book checkouts is low, but has remained relatively unchanged at around 4\%. It should be noted that the circulation rates for each year were based on 2011 holdings data, and as holdings tend to increase each year, the circulation rate for earlier years was probably slightly higher than indicated, and the decline in circulation correspondingly somewhat greater.

\section{Table 4 about here}

Following the recommendation of Anderson (2011), I calculated checkouts per enrolled student for 2005-2009. Unfortunately the WCA tool does not provide “initial checkouts,” so the checkout data include renewals. I used data for students enrolled in the spring semester of each year from the 2010-2011 SHU Fact Book’s “enrollment by college” table (p. \#31). Full-time enrollment increased by $0.4 \%$ between 2005 and 2009, but number of checkouts per full-time student decreased by $23.3 \%$, from 6.7 to 5.1 (see Table 4 ). This is very similar to the $23 \%$ decrease that I calculated for the overall circulation rate during the same 5-year period. 
The WCA does not provide current circulation data, but our systems librarian was able to obtain circulation statistics for the period July 2010-2011 from our Voyager system. This showed an overall checkout rate of 7.3\%, slightly higher than the 6.8\% returned by the WCA for 2009 . These figures are not directly comparable due to discrepancies between Voyager and OCLC holdings data and the discrepancy between calendar year (WCA) and academic year (Voyager). However, both the WCA data and the Voyager data show similar patterns and subject-based variation in circulation, with health and medical science books having the highest circulation rates and science and business books the lowest. Checkouts per full-time student for July 201011 (based on Voyager data and enrollment figures for fall 2010) were 4.8 compared with 5.1 in 2009.

Voyager also provides data for print book circulation by patron type. In July 2010-11, over two-thirds of circulating books were checked out by Seton Hall students -- 45\% by undergraduates and $22 \%$ by graduate students. Only $6 \%$ of checkouts were to faculty, $8 \%$ were to other Seton Hall patrons (mainly administrators and staff), and over $18 \%$ were interlibrary loans or loans to non-SHU patrons with borrowing privileges. Based on fall 2010 full-time student enrollment, SHU undergraduates checked out an average of 3.7 books and graduate student checked out an average of 6.5 books in July 2010-11. If part-time students are included, the averages fall to 3.4 and 2.5 respectively, reflecting the fact that over $60 \%$ of our graduate students are enrolled part-time.

\section{Circulation of Science Books}

I undertook a detailed analysis for our science collection and circulation as part of a larger project comparing data from our Voyager system with our holdings data in OCLC. 
Circulation data from Voyager were provided by our systems librarian. I obtained OCLC data using the WCA. I created a subject profile for science and technology and limited my analyses to that profile and to books.

The respective numbers for overall science book holdings differed by only $2.5 \%$ and circulation rates were similar (see Table 5). Both Voyager and the WCA showed that about 12\% of science books circulated at least once between 2005 and 2009, with Voyager showing slightly higher average times checked out of 1.79 compared to 1.66. Voyager data indicate that science books published since 2000 were checked out an average of 2.33 times compared to the WCA value of 2.02 times. The reason for the discrepancies are not clear. Both Voyager and WCA data show about one third of science books published since 2000 were checked out at least once between 2005 and 2009, with values declining sharply for older books (see Figure 1). Based on WCA data, almost two-thirds of all science checkouts were for books published since 1990 (see Table 6). The percentage of expected use (PEU) for all books published prior to 1990 are below 100\%, while the PEU for 1990s and 2000s books are 196\% and 280\% respectively.

\section{Table 5 about here}

Table 6 about here

\section{Table 7 about here}

I calculated the number of declared science majors and science graduate students from data provided in the 2010-11 SHU fact book. The number of science book checkouts per science student was 2.3 (1,246 checkouts / 553 students). The number of science book checkouts per full-time science student was 2.7 (1246 checkouts / 464 students), considerably lower than the 5.1 checkouts calculated for all full-time students (see Table 4). 
Voyager can also provide circulation data by book location. The majority (95.2\%) of our science books are in the main (available to circulate) collection (see Table 5). Circulation figures for the main collection were close to the average for all science books: $12.1 \%$ circulated at least once between 2005 and 2009, and these were checked out an average of 1.8 times. Circulation rates for the main science collection highlight the contrast between the age of the collection and use of the collection: Only 9.2\% of main collection science books were published since 2000, but 36\% circulated at least once between 2005 and 2009 (see Figure 2). By contrast, $22 \%$ of the collection dates from the 1970 s, and only $7 \%$ of the 1970 s books circulated. There is a similar pattern for times checked out: Circulating books published since 2000 were checked out an average of 2.3 times, while those from the 1970s were checked out an average of 1.4 times.

Figure 2 about here.

\section{Circulation of Print Books Compared with Use of E-books}

In May 2009, our business librarian and I began a pilot e-book project with ebrary. We subscribed to a large business collection and purchased 65 recently published, individually selected science and health science titles. Statistics obtained through the ebrary reporting portal showed that only $7.2 \%$ of the business collection was used in the first year, but use of the purchased collection was higher, with $48 \%$ viewed at least once in the first year (Stern \& Wiles, 2010). The average number of user sessions for the purchased collection in the first year was 8.8 (range 1-146). The average number of pages viewed was 118 (range 1-3038), with 31\% of books that were viewed showing use of more than ten pages. The average percentage of a book that was viewed was $8.8 \%$ (range $<1 \%$ - 95\%). Excluding one exceptionally high-use title that was used as a textbook in fall 2009, the average number of user sessions in the first year of our pilot was 
4.2 (range 1-13), the average number of pages viewed was 21 (range 1-145) and the average percentage of a book that was viewed was $1.8 \%$ (range $<1 \%$ - 9\%).

I gradually added titles to the purchased collection, which totaled 214 by the end of 2011. Ebrary statistics for calendar year 2011 show that 109 (51\%) of e-books in the purchased collection were viewed at least once, while ebrary' s counter statistics give a slightly higher use rate of 55\%. The average number of user sessions for e-books that were used was 3.5 (range 126). An average of 75 pages were viewed per use (range 1-1145), with 33\% of e-books viewed showing use of more than 10 pages. The average percentage of a book that was viewed was $9 \%$ (range $<1 \%$ - 93\%). Excluding one book that showed 93\% of pages viewed, average user sessions remained at 3.5, average pages viewed were 65 (range 1-590) and average percentage of a book that was used was $8.2 \%$ (range $<0 \%-53 \%$ ).

\section{Discussion}

\section{OCLC WorldCat Analysis Tool}

The WCA proved very useful in providing an overview of our print book collection and circulation. It is not particularly intuitive or flexible, and there is definitely "a learning curve associated with using this tool to mine, manipulate, and interpret the data” (Davis et al., 2008, p. 244). An advantage of the WCA is the ability to export results as text files that can be imported into Excel and manipulated there, but the process is still cumbersome and time consuming.

One issue is the lack of clarity regarding what WCA counts as "a book," and whether multivolume sets, books with associated media, or multiple copies of a single work are consistently counted as single or multiple items. In this study, the similarity between holdings data obtained from the WCA and our own Voyager system is reassuring, but the issue could be more significant if one were comparing a collection with those held by other libraries. Indeed, defining 
what constitutes "a book" was one of the first steps in the circulation analysis undertaken by Knievel et al. (2006).

It would be helpful if older and more recent circulation periods were available beyond the current 2005-9. As it is now 2012, it is frustrating to find that the WCA does not provide any circulation data for 2010 or 2011. A particularly useful option would be the ability to check holdings and circulation of books added to a library since a specific date or within a range of dates. This would allow librarians to easily determine, for example, the proportion of books acquired in 2010 that circulated within their first year or within five years, as considered by Mallery \& Theus (2011).

Finally, a limitation of the WCA circulation analysis, shared by all machine-based circulation analyses, is that it does not capture books that have been used within the library or books that have been taken from the library without being checked out.

\section{SHU Collections and Circulation}

Our print book collection is clearly much stronger in the humanities than in other areas, which reflects both the emphasis on humanities studies at SHU and the NEH grant that allows us to purchase comprehensively in humanities subjects. Our print collections in other areas, particularly business and the sciences, are strong in earlier decades but less so for more recently published books. Our collection of science books published in the 1970s is a good example of the "golden days" of academic libraries, when almost all new books in a subject area could be purchased in case a need arose, and multiple copies of high-demand books could be proudly displayed. Our recent collections reflect a shift toward smaller-scale acquisition practices due to a combination of budget and space constraints, growing demand for and reliance on electronic 
resources, and a perception that print books are no longer a priority for users in many disciplines, particularly the sciences.

Our circulation data seem to confirm the low demand for print books, especially in the sciences. On average, less than one quarter of our holdings circulated at all in the 5-year period 2005 - 2009, and books that did circulate were only checked out an average of 1.88 times. This seems low in comparison with other studies. For example Cheung et al. (2011) reported that 65\% of books added to the Lingnan University library collection between 1995 and 2009 had been checked out at least once, and Blecic (2000) reported that 81.5\% of monographs circulated at least once during their first 3 years of shelf life at the Chicago Library of Health Sciences. However, these high circulation rates include only relatively recent books, while ours represent our entire collection, including many older books. A more comparable study is that of Knievel et al. (2006), who reported circulation rates of different subject collections at the University of Colorado in Boulder within a 5-year period ranged from $15 \%$ to $43 \%$. I found similar variation by subject but generally lower circulation rates, ranging from $9 \%$ for literature and languages to $29 \%$ circulation of art books.

The SHU circulation data illustrate not only subject-based variation in print book circulation, but also the influence of publication date. The positive correlation between the proportion of recent books in a subject collection and the proportion circulated is consistent with the strong evidence from our science book circulation data that new books are used far more than older books. Over one-third of science books published since 2000 circulated at least once (on average more than twice) between 2005 and 2009, while circulation rates for older books fell from $25 \%$ for 1990 s books to $11 \%$ for 1980 s books. 
The percentage of expected use (PEU) data also show differences among subject collections. Only sociology had a PEU more than one standard deviation from the mean (Aguilar's 1986 measure of an "over-used” collection), but sociology, health and medical sciences, political science, history, education, and arts all showed PEUs of over $110 \%$. Business and science were among the lowest scores, with science showing a PEU of only 50\%, indicating that the collection as a whole is substantially under-used. It is likely no coincidence that these are the most dated collections in fields where currency is important. Calculating PEU data for science books by date range further illustrates the importance of currency on circulation in the sciences. Our 1990s and 2000s collections clearly qualify as “over-used,” with PEUs of 196\% and 280\% respectively, while all older books have PEUs below 100\%. Despite these results, it is important to note that some older science books still do circulate and may be valuable to our collections.

In keeping with many reports in the literature, I found that print book circulation at SHU has declined over the past 5 years. Overall circulation rates and circulation rates per student show a similar decline of about 23\%. Surprisingly, the circulation of science books, although consistently low, has not declined particularly in the past 5 years. However, the number of checkouts per science student in 2010-11 was only 56\% of the average for all full-time students, confirming the overall tendency for scientists to rely heavily on electronic resources such as articles, conference material, and other forms of scholarly communication.

A final point from my analyses is that although $75 \%$ of print books that circulated between July 2010-11 were checked out by SHU students or faculty, over 18\% were checked out by non-SHU patrons, primarily as interlibrary loan requests. This indicates that our collection serves not only our own constituency but, in accordance with our Catholic Mission, we serve a 
wider community. It may also be that non-SHU constituents have a greater demand for print books than our faculty and students, who have extensive access to online materials and a campus that has long been recognized as "wired" in terms of access to computers and technology.

\section{Why Is Our Print Book Circulation Low?}

The two most likely reasons for low print book circulation are that our collections do not match our users' needs or that their need for print books overall is low. This study cannot differentiate between these factors, but the aging nature of some of our collections coupled with the growing dependence on articles and "instant" communication in academia suggest that both are likely significant. Informal conversation and experiences at the reference desk indicate that the majority of students are seeking articles rather than books.

It is also possible that our users do use print books, but are not necessarily going to the library to find them. The main books that students (especially undergraduates) seek and expect to find in our library are their textbooks. As we do not routinely acquire textbooks unless professors provide them, students are often disappointed and may make a larger assumption that "the library will not have the books I need." Tenopir et al. (2012) suggest reasons that the library may not be faculty’s primary source of books include publishers providing free review copies, and that obtaining existing books or requesting new books from the library may not be fast or efficient. Related to this may be a growing culture of buying books direct from publishers or vendors such as Amazon rather than borrowing books from the library, which may be the result of wide-scale advertising by these book sellers. Finally, the ongoing need for re-shelving clearly shows that books are used in the library without being checked out, while other books simply disappear from the collection. At present we do not monitor the use of print materials in 
the library or missing books in a consistent manner, but doing so could help shed further light on the demand for print books.

\section{How Does Use Of E-Books Compare with Print Books?}

E-book and print book use rates are notoriously difficult to compare, but using the criterion of ten or more pages viewed as equivalent to a checkout, use of e-books and recent print books in the sciences are similar at about one-third. A few e-books experienced very high-use, especially one that was adopted for a class in fall 2009, but overall use of e-books at SHU has been conservative. This may be because the e-book collection is relatively small and unpublicized. Based on informal questioning, most students are not aware that we have e-books and are pleased to find that we do, but some indicate that they dislike e-books and prefer print. The ebrary usage data for our small collection confirm the conclusions of other studies that ebooks are browsed or searched rather than read in their entirety. The average proportion of a book that was viewed increased from 2\% in the first year of our e-book pilot to $9 \%$ in 2011, but this still suggests searching, browsing, or perhaps reading a single chapter rather than reading an entire book in electronic format.

\section{OUTCOMES AND BENEFITS OF OUR CIRCULATION ANALYSIS}

The first outcome of the circulation analysis was a comprehensive weeding of print science books, beginning with the reference collection. After consultation with science faculty, many of our older reference books were relocated to our main collection, discarded, or donated. Weeding of the main science collection began in conjunction with an extensive inventory project coordinated by our associate dean (Loesch, 2011). I requested that the Library of Congress Q section be reviewed early in the inventory project, and subsequently inspected all books that were removed from the shelves as problems. Examples included books that were on the shelf 
but not in our online catalog or not on the inventory list, incorrect call numbers or barcodes, and books in poor condition. Over 800 books were removed from the main science collection in conjunction with the inventory, primarily books published prior to 1990 . Weeding of the science collection is ongoing, with a goal of reducing the number of books that are more than 20 years old by at least 20\%. A full-scale weeding of the reference collection has recently been undertaken for all subject areas.

One caveat regarding weeding older books is that some are still valuable and/or used. Diligent weeding often includes checking circulation records, holdings of a book in other libraries, availability and price at online book vendors such as Amazon and Alibris, and in some cases contacting appropriate departments and faculty. Extensive weeding also involves a heavy time investment, especially by technical services personnel who must remove catalog records and physically relocate or discard an unusually large volume of books. However, we feel that weeding is well worth the effort if the result is an improved catalog, updated and more attractive collections, and improved circulation.

The science circulation analysis also informed collection development by identifying heavily used books and specific topics with high usage. For example, I used the WCA tool to identify science titles checked out more than ten times between 2005 and 2009 ( $n=21)$ and books published since 2000 that had been checked out six to ten times between 2005 and $2009(\mathrm{n}=50)$. I used this information to order additional copies and/or more recent editions and related titles. A follow up to this project will be to examine our interlibrary loan requests to further inform collection development, and to obtain updated syllabi from teaching faculty to help us better support curricular requirements. 
A further outcome of the circulation analysis is SHU Libraries' participation in the international Scholarly Reading and Value of Library Resources project “LibValue,” which measures the value and outcomes of access to scholarly publications (Tenopir et al., 2011; 2012). Invitations to complete an online survey of scholarly article and book reading behavior were sent to all SHU faculty and students in March 2012. The results are currently under analysis and should shed light on patterns of use of both online resources and print books.

Finally, the low circulation of print books in many areas was a major factor in our decision to begin an e-book PDA program with ebrary. We followed the approach of Dinkins (2012) by individually selecting titles to include in PDA profiles. Records for all PDA titles are uploaded into our online catalog. Over 1,500 science and health science titles have been added since we began our PDA pilot in October 2011, and PDA offerings in other subject areas are increasing after an initial slow start. As invoices are received from ebrary only if and when titles are triggered for purchase, so the PDA is an excellent way to offer a wide selection of titles without incurring immediate costs. The library only pays for books that are actually used and need not pay for unused books. This is an especially important consideration in the sciences, where books are often more expensive than those in other disciplines. There are also savings in the processing and maintenance costs associated with print books, saved shelf space, and reduced potential for overdue, lost, or stolen books.

While the PDA is not a panacea for declining budgets and low circulation, the move from a "just in case" toward a "just in time” model of collection development should help us to improve our collections in a cost-effective manner. In addition, examining which titles are triggered and patterns of e-book use will help inform future collection development as well and allow us to better match our e-book and print book collections to our users’ needs. 
We do not expect e-books to replace print books. Not all books that we wish to acquire for our collections are available in e-format, and some publishers delay the release of new titles as ebooks for fear of compromising their print books sales. Many publishers do not participate in PDA models, and some offer only pre-selected packages. Small, specialized, and non-profit publishers may be especially unwilling or unable to enter the competitive e-book market, and we will likely continue to rely on such publishers for some of our books. Despite some advances in e-book technology, some users will undoubtedly continue to prefer print books, particularly if they wish to read a book in its entirety rather than search or browse it. In addition, there is the complex and thorny issue of interlibrary loans, which current e-book models do not support. However, we hope that e-books will complement our print book collection, offer our users a much wider selection of titles, and possibly increase the use of print books as reported by Henry et al. 2008.

Introducing a patron-driven e-book program, weeding little-used books, and using circulation data and user feed-back to inform collection development should improve the match between our users' needs and library holdings. Ultimately this will enhance the value of our collections and our library, and support our library mission to serve as a vital link to our students and faculty for their information and research needs. 


\section{References}

ACRL Research Planning \& Review Committee. (2012). 2012 top ten trends in academic libraries. College \& Research Libraries News, 73(6), 311-320.

“ACRLMetrics,” accessed February 18, 2012, http://www.acrlmetrics.com.

Aguilar, W. (1986). The application of relative use and interlibrary demand in collection development. Collection Management, 8(1), 15-24.

Anderson, R. (2011). Print on the margins. Library Journal, 136(11), 38-39.

Beals, J. B., \& Gilmour, R. (2007). Assessing collections using brief tests and WorldCat collection analysis. Collection Building, 26(4), 104-107.

Berg, S. A., Hoffmann, K., \& Dawson, D. (2010). Not on the same page: Undergraduates' information retrieval in electronic and print books. Journal of Academic Librarianship, 36(6), 518-525.

Blecic, D. D. (2000). Monograph use at an academic health sciences library: The first three years of shelf life. Bulletin of the Medical Library Association, 88(2), 145-151.

Blummer, B., \& Kenton, J. (2012). Best practices for integrating e-books in academic libraries: A literature review from 2005 to present. Collection Management, 37(2), 65-97.

Bonn, G. S. (1974). Evaluation of the collection. Library Trends, 22(3), 265-304.

Bullis, D. R., \& Smith, L. (2011). Looking back, moving forward in the digital age: A review of the collection management and development literature, 2004-8. Library Resources \& Technical Services, 55(4), 205-220.

Carlson, S. (2001). The deserted library. Chronicle of Higher Education, 48(12), A35.

Carrigan, D. P. (1996). Data-guided collection development: A promise unfulfilled. College \& Research Libraries, 57(5), 429-437.

Cheung, S., Chung, T., \& Nesta, F. (2011). Monograph circulation over a 15-year period in a liberal arts university. Library Management, 32(6), 419-434.

Christianson, M. (2005). Patterns of use of electronic books. Library Collections, Acquisitions, and Technical Services, 29(4), 351-363.

Christianson, M., \& Aucoin, M. (2005). Electronic or print books: Which are used? Library Collections, Acquisitions, and Technical Services, 29(1), 71-81. 
Connaway, L., \& Wicht, H. (2007). What happened to the e-book revolution?: The gradual integration of e-books into academic libraries. Journal of Electronic Publishing, 10(3). Accessed May 5, 2012. http://quod.lib.umich.edu/cgi/t/text/textidx?c=jep;cc=jep;rgn=main;view=text;idno=3336451.0010.302

Cox, J. (2008). Making sense of E-book usage data. Acquisitions Librarian, 19(3), 193-212.

Culbertson, M., \& Wilde, M. (2009). Collection analysis to enhance funding for research materials. Collection Building, 28(1), 9-17.

Davis, H.D., Day, A., \& Orcutt, D. (2008). Further reflections on the WorldCat collection analysis tool. Collection Management, 33(3), 236.

Dillon, D. (2001). E-books: The University of Texas experience, part 1. Library Hi Tech, 19(2), $113-125$.

Dinkins, D. (2003). Circulation as assessment: Collection development policies evaluated in terms of circulation at a small academic library. College \& Research Libraries, 64(1), 46-53.

Dinkins, D. (2012). Individual title requests in PDA collections. College \& Research Libraries News, 73(5), 249-255.

Eldredge, J. D. (1998). The vital few meet the trivial many: Unexpected use patterns in a monographs collection. Bulletin of the Medical Library Association, 86(4), 496-503.

Henry, E., Longstaff, R., \& van Kampen, D. (2008). Collection analysis outcomes in an academic library. Collection Building, 27(3), 113-117.

Hodges, D., Preston, C., \& Hamilton, M. J. (2010). Patron-initiated collection development: Progress of a paradigm shift. Collection Management, 35(3), 208-221.

Hughes, M. (2012). Assessing the collection through use data: An automated collection assessment tool. Collection Management, 37(2), 110-126.

Jackson, M. (2008). What faculty think: A survey on electronic resources. Journal of Electronic Resources Librarianship, 20(2), 110-116.

JISC national e-books observatory project: Key findings and recommendations Final Report, November 2009. Accessed July 3, 2012. http://observatory.jiscebooks.org/reports/jisc-national-e-books-observatory-project-keyfindings-and-recommendations/

Kimball, R., Ives, G., \& Jackson, K. (2010). Comparative usage of science e-book and print collections at Texas A\&M university libraries. Collection Management, 35(1), 15-28. 
Knievel, J. E., Wicht, H., \& Connaway, L. S. (2006). Use of circulation statistics and interlibrary loan data in collection management. College \& Research Libraries, 67(1), 35-49.

Kolowich, S. (2011). A truly bookless library. Education Digest, 76(5), 35-36.

Kraus, J. (2009). Comparing bananas with grapes: E-book use data from a bunch of vendors. Brick and Click Libraries Symposium Proceedings November 6, 2009. 178-188.

Kyrillidou, M., \& Morris, S. (2011). ARL statistics 2008-2009. Accessed June 3, 2012 http://www.arl.org/bm doc/arlstat09.pdf

Littman, J. (2002). A preliminary comparison of electronic book and print book usage in Colorado. Colorado Libraries, 28(3), 39-41.

Littman, J., \& Connaway, L. S. (2004). A circulation analysis of print books and e-books in an academic research library. Library Resources \& Technical Services, 256-262.

Loesch, M.F. (2011). Inventory redux: A twenty-first century adaptation. Technical Services Quarterly 28(3), 301-311. Available at: http://works.bepress.com/martha_loesch/1

Long, M. P., \& Schonfeld, R. C. (2010). Ithaka S R library survey 2010: Insights from U.S. academic library directors. New York, NY: Ithaka S+R.

Mallery, M. \& Theus, P. (2012). New frontiers in collaborative collection management. Technical Services Quarterly, 29(2), 101112.

Martell, C. (2008). The absent user: Physical use of academic library collections and services continues to decline 1995-2006. The Journal of Academic Librarianship, 34(5), 400407.

McClure, J. Z. (2009). Collection assessment through WorldCat. Collection Management, 34(2), 79-93.

McKiel, A. (2012). 2011 global student e-book survey. Accessed June 27, 2012. http://www.ebrary.com/corp/newspdf/ebrary_student_survey_report.pdf

Miller, R. (2011). Dramatic growth. Library Journal, 136(17), 32-34.

Mills, T. R. (1982). The university of Illinois film center collection use study. Report no: ED 227 821,

Monroe-Gulick, A., \& Currie, L. (2011). Using the WorldCat collection analysis tool: Experiences from the University of Kansas Libraries. Collection Management, 36(4), 203-216. 
Neubert, M., \& Brewer, M. (2007). Identifying holdings unique to your library's collections using WorldCat. Slavic \& East European Information Resources, 7(4), 115-121.

Nixon, J. M., Freeman, R. S., \& Ward, S. M. (2010). Patron-driven acquisitions: An introduction and literature review. Collection Management, 35(3), 119-124.

OCLC (no date). Introduction to the WorldCat Collection Analysis Service. Accessed July 21, 2012.

http://www.oclc.org/support/documentation/collectionanalysis/using/introduction/introd uction.htm

Ochola, J. N. (2002). Use of circulation statistics and interlibrary loan data in collection management. Collection Management, 27(1), 1-13.

Orcutt, D., \& Powell, T. (2006). Reflections on the OCLC WorldCat collection analysis tool: We still need the next step. Against the Grain, 18(5), 44-48.

Price, J. S., \& McDonald, J. D. (2009). Beguiled by bananas: A retrospective study of the usage and breadth of patron vs. librarian acquired e-book collections. Presentation on e-book acquisition at academic libraries given at the XXIX Annual Charleston Conference: Issues in Book and Serial Acquisition on November 5, 2009. Accessed September 20, 2012. http://www.slideshare.net/john_mcdonald/charleston2009-ebookjspjdm

Rose-Wiles, L. M. (2011). The high cost of science journals: A case study and discussion. Journal of Electronic Resources Librarianship, 23(3), 219-241.

Schonfeld, R. C., \& Housewright, R. (2010). Ithaka S+R faculty survey 2009: Key strategic insights for libraries, publishers, and societies Ithaka S+R New York, NY.

Seton Hall University Fact book, 2010-11, accessed May 31, 2012. http://www.shu.edu/offices/upload/2010-11-Fact-Book.pdf

Shelburne, W. A. (2009). E-book usage in an academic library: User attitudes and behaviors. Library Collections, Acquisitions, and Technical Services, 33(2), 59-72.

Shen, L., Cassidy, E.D., Elmore, E., Griffin, G., Manolovitz, T., Martinez, M. \& Turney, L.M. (2011). Head first into the patron-driven acquisition pool: A comparison of librarian selections versus patron purchases. Journal of Electronic Resources Librarianship, 23(3), 203-218S

Shrimplin, A. K., Revelle, A., Hurst, S., \& Messner, K. (2011). Contradictions and consensusclusters of opinions on e-books. College \& Research Libraries, 72(2), 181-190.

Slater, R. (2009). E-books or print books, “big deals” or local selections-What gets more use? Library Collections, Acquisitions, and Technical Services, 33(1), 31-41. 
Sprague, N., \& Hunter, B. (2009). Assessing e-books: Taking a closer look at e-book statistics. Library Collections, Acquisitions, and Technical Services, 32(3-4), 150-157.

Stewart, C. (2011a). The next chapter: Measuring the pace of change for print monograph collections. The Journal of Academic Librarianship, 37(4), 355-357.

Stewart, C. (2011b). An overview of ACRLMetrics. The Journal of Academic Librarianship, 37(1), 73-76.

Stern, R. and Rose-Wiles, L. (2010). Seton Hall University ebrary Collection. Presented at NJLA College and University Section Technology Committee/VALE e-books Collections Task Force eBook Collections Symposium, Montclair State University, N.J., $5 / 21 / 10$.

Tenopir, C., Volentine, R., \& King, D. W. (2011). UK Scholarly reading and the value of academic library collections: Results of a study conducted Spring 2011. Accessed August 4, 2012. http://www.jisccollections.ac.uk/Documents/Reports/UK\%20Scholarly\%20Reading\%20and\%20the\%20 Value\%20of\%20Library\%20Resources\%20Final\%20Report.pdf

Tenopir, C., Volentine, R., \& King, D. W. (2012). Scholarly reading and the value of academic library collections: Results of a study in six UK universities. Insights: The UKSG Journal, 25(2), 130-149.

Trueswell, R. L. (1969). Some behavioral patterns of library users: The 80/20 rule. Wilson Library Bulletin, 43(5), 458-461.

Ugaz, A., \& Resnick, T. (2008). Assessing print and electronic use of reference/core medical textbooks. Journal of the Medical Library Association, 96(2), 145-147.

Way, D. (2009). The assessment of patron-initiated collection development via interlibrary loan at a comprehensive university. Journal of Interlibrary Loan, Document Delivery \& Electronic Reserves, 19(4), 299-308.

Williams, C. W., \& Best, R. (2006). E-book usage and the choice outstanding academic book list: Is there a correlation? The Journal of Academic Librarianship, 32, 474-478.

Woody, W. D., Daniel, D. B., \& Baker, C. A. (2010). E-books or textbooks: Students prefer textbooks. Computers \& Education, 55(3), 945-948.

Received: August 7, 2012

Accepted: September 15, 2012 
Table 2: Circulation for 2005-2009 vs Proportion of Books and Currency of Subject Collection, Based on OCLC Data.

\begin{tabular}{|c|c|c|c|c|c|}
\hline Subject & $\begin{array}{c}\text { Subject area as \% } \\
\text { of SHU book } \\
\text { collection }^{1}\end{array}$ & $\begin{array}{c}\text { Subject area as } \\
\% \text { of total books } \\
\text { published since } \\
2000\end{array}$ & $\begin{array}{c}\text { \% of books in } \\
\text { subject area } \\
\text { published since } \\
2000\end{array}$ & $\begin{array}{c}\text { \% of books in } \\
\text { subject area } \\
\text { circulated 2005-9 }\end{array}$ & $\begin{array}{c}\text { Average } \\
\text { checkouts for } \\
\text { books in subject } \\
\text { area 2005-9 }\end{array}$ \\
\hline Arts & $6.5 \%$ & $12.6 \%$ & $34.4 \%$ & $28.6 \%$ & 1.73 \\
\hline Sociology & $4.1 \%$ & $4.3 \%$ & $18.4 \%$ & $27.9 \%$ & 2.05 \\
\hline History & $15.4 \%$ & $19.2 \%$ & $22.0 \%$ & $25.0 \%$ & 1.95 \\
\hline Health \& Medical Sciences & $5.0 \%$ & $4.7 \%$ & $16.4 \%$ & $23.9 \%$ & 2.13 \\
\hline Political Science & $3.0 \%$ & $2.5 \%$ & $14.8 \%$ & $23.7 \%$ & 2.08 \\
\hline Education & $3.8 \%$ & $3.7 \%$ & $17.1 \%$ & $23.4 \%$ & 1.96 \\
\hline Anthropology & $0.6 \%$ & $1.1 \%$ & $30.0 \%$ & $23.0 \%$ & 1.83 \\
\hline Psychology & $1.1 \%$ & $0.7 \%$ & $12.0 \%$ & $22.7 \%$ & 1.90 \\
\hline Criminal justice/law & $1.3 \%$ & $1.1 \%$ & $14.6 \%$ & $21.5 \%$ & 1.82 \\
\hline Other & $2.9 \%$ & $1.9 \%$ & $19.8 \%$ & $21.1 \%$ & 1.88 \\
\hline Philosophy \& Religion & $16.6 \%$ & $15.0 \%$ & $16.0 \%$ & $20.9 \%$ & 1.89 \\
\hline Business \& Economics & $6.6 \%$ & $4.2 \%$ & $11.1 \%$ & $18.1 \%$ & 1.73 \\
\hline Science & $6.4 \%$ & $3.9 \%$ & $10.9 \%$ & $12.2 \%$ & 1.66 \\
\hline Literature \& Languages & $20.3 \%$ & $22.8 \%$ & $11.7 \%$ & $9.2 \%$ & 1.68 \\
\hline Average & & $7.0 \%$ & $17.8 \%$ & $21.5 \%$ & 1.88 \\
\hline
\end{tabular}


Table 3: Holdings, Circulation and Percentage or Expected Use of Print Books by Subject Area.

\begin{tabular}{|c|c|c|c|c|c|}
\hline Subject Area & Holdings & $\begin{array}{l}\% \text { of total } \\
\text { collection }\end{array}$ & $\begin{array}{c}\text { Checkouts } \\
\text { 2005-9 }\end{array}$ & $\begin{array}{c}\% \text { of total checkouts } \\
2005-9\end{array}$ & PEU $^{1}$ \\
\hline Sociology & 18,180 & 4.37 & 10,397 & 6.12 & $140 \%$ \\
\hline Health \& Medical Sciences & 22,376 & 5.38 & 11,352 & 6.69 & $124 \%$ \\
\hline Political science & 13,245 & 3.19 & 6,519 & 3.84 & $120 \%$ \\
\hline History & 68,219 & 16.42 & 33,304 & 19.62 & $119 \%$ \\
\hline Education & 16,918 & 4.07 & 7,759 & 4.57 & $112 \%$ \\
\hline Arts & 28,729 & 6.91 & 13,034 & 7.68 & $111 \%$ \\
\hline Psychology & 4,723 & 1.14 & 2,043 & 1.20 & $106 \%$ \\
\hline Anthropology & 2,883 & 0.69 & 1,214 & 0.72 & $103 \%$ \\
\hline Literature \& Language & 90,278 & 21.72 & 35,833 & 21.11 & $97 \%$ \\
\hline Philosophy / Religion & 73,758 & 17.75 & 29,123 & 17.15 & $97 \%$ \\
\hline Law / Criminal Justice & 5,947 & 1.43 & 2,325 & 1.37 & $96 \%$ \\
\hline Business & 29,194 & 7.02 & 9,168 & 5.40 & $77 \%$ \\
\hline Science & 28,210 & 6.79 & 5,705 & 3.36 & $50 \%$ \\
\hline Other & 12,913 & 3.11 & 2,005 & 1.18 & $38 \%$ \\
\hline Total/average & 415,573 & & 169,781 & & $99 \%$ \\
\hline
\end{tabular}

Percentage of expected use $=\%$ total books checkouts $/ \%$ of total book holdings $* 100$. Excludes government documents. Includes 585 books with no publication date recorded.

Values > 1 S.D. (28\%) from mean are in bold type. 
Table 4: Total Checkouts as a Percentage of Total Holdings by Subject Area, 2005-2009, Based on OCLC Data for 170,590 checkouts. ${ }^{\circledR}$

\section{Broad Subject Area}

Health \& Medical sciences

Social Science

Humanities

Business

Science

All subjects ${ }^{1}$

Total checkouts ${ }^{1}$

Checkouts per full-time student

$\begin{array}{cc} & \begin{array}{c}\text { checkout rat } \\ \text { checkout rate 2005 }\end{array} \\ 11.4 \% & 10.7 \% \\ 10.7 \% & 11.3 \% \\ 8.9 \% & 9.5 \% \\ 6.7 \% & 6.7 \% \\ 3.7 \% & 4.1 \% \\ \mathbf{8 . 1 \%} & \mathbf{8 . 5 \%} \\ 36,012 & 37,823 \\ 6.7 & 7.2\end{array}$

checkout rate

2007

$10.1 \%$

$9.8 \%$

$8.9 \%$

$5.9 \%$

$4.3 \%$

$7.9 \%$

34,975

6.6 checkout rate

2009

$9.3 \%$

$8.2 \%$

$6.7 \%$

$5.6 \%$

$3.9 \%$

$6.2 \%$

27,738

5.1

${ }^{1}$ includes government documents and "other." 


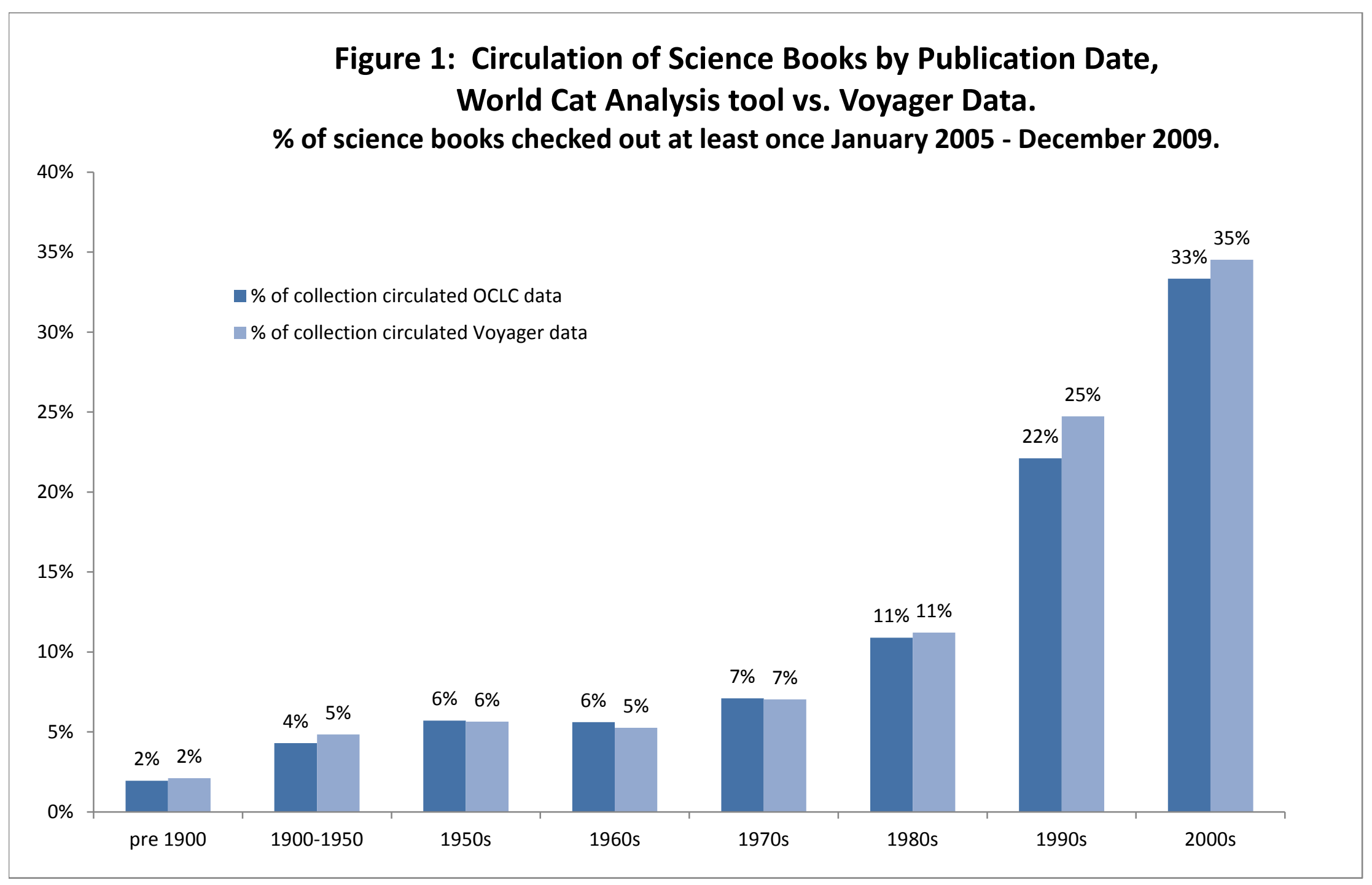




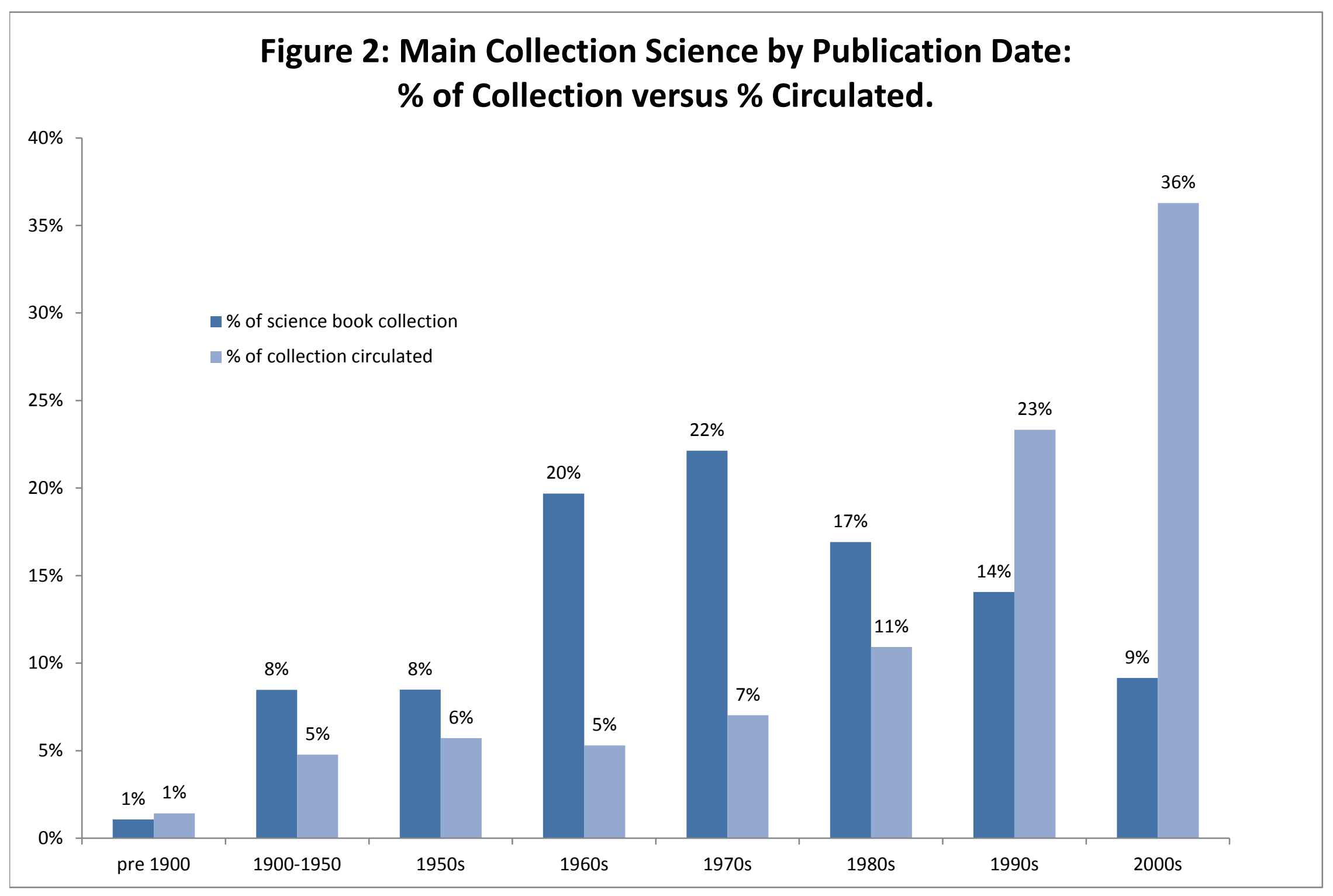

